\title{
Ran-Binding Protein 17
}

National Cancer Institute

\section{Source}

National Cancer Institute. Ran-Binding Protein 17. NCI Thesaurus. Code C97756.

Ran-binding protein 17 (1088 aa, 124 kDa) is encoded by the human RANBP17 gene.

This protein may play a role in the modulation of nuclear import or export. 